\title{
Idiomarina gen. nov., comprising novel indigenous deep-sea bacteria from the Pacific Ocean, including descriptions of two species, Idiomarina abyssalis sp. nov. and Idiomarina zobellii sp. nov.
}

\author{
Elena P. Ivanova, ${ }^{1,2}$ Ludmila A. Romanenko, ${ }^{2}$ Jongsik Chun, ${ }^{1} \dagger$ \\ Maria H. Matte, ${ }^{1,3}$ Glavur R. Matte, ${ }^{1,3}$ Valery V. Mikhailov, ${ }^{2}$ \\ Vasilii I. Svetashev, ${ }^{2}$ Anwarul Huq, ${ }^{1,5}$ Tim Maugel $^{4}$ and Rita R. Colwell ${ }^{1,5}$
}

Author for correspondence: Rita R. Colwell. Tel: +1 703306 1000. Fax: + 17033060109 e-mail: colwell@umbi.umd.edu

1 Center of Marine Biotechnology, University of Maryland Biotechnology Institute, 701 E. Pratt St, Baltimore, MD 21202, USA

2 Pacific Institute of Bioorganic Chemistry of the Far-Eastern Branch of the Russian Academy of Sciences, 690022

Vladivostok, Pr. 100 Let

Vladivostoku 159, Russia

${ }^{3}$ School of Public Health, University of Sao Paulo, Av. D. Arnaldo, 715, 012466904, Brazil

4,5 Department of Zoology4, and Department of Cell Biology and Molecular Biology (CBMB) 5 , University of Maryland, College Park, MD 20742, USA

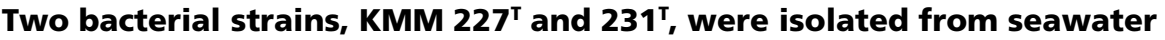
samples collected from the north-western Pacific Ocean at a depth of 4000-5000 m and were characterized using polyphasic taxonomy. Both were Gram-negative, psychrotolerant, heterotrophic, aerobic and required $\mathrm{NaCl}$ for growth (0.6-15.0\%). The temperature for growth was 4-30 ${ }^{\circ} \mathrm{C}$. Both strains were rod-shaped, with a single flagellum. However, strain KMM $231^{\top}$ revealed a single long fimbrium. Cellular fatty acids detected in the isolates were predominantly odd-numbered and iso-branched, with 15 and 17 carbons (ca. $70 \%$ ). Also present were saturated and monounsaturated straight-chain fatty acids. Results of phylogenetic analyses, employing three tree-making methods, strongly indicated that the two strains formed a distinct lineage within a clade containing the genera Alteromonas, Colwellia and Pseudoalteromonas, in the $\gamma$-Proteobacteria. The two strains shared 16S rDNA sequence similarity of $96.9 \%$ and genomic DNA relatedness of $27 \%$; the latter was determined by dot-blot hybridization. The strains were differentiated by the presence of fimbria, production of chitinase, ability to grow on $15 \% \mathrm{NaCl}$ and $\mathrm{BIOLOG}$ profiles. Given the polyphasic evidence accumulated in this study, it is proposed that the two deep-sea isolates be classified in the genus Idiomarina gen. nov., as Idiomarina abyssalis sp. nov. (type strain is KMM $227^{\top}$ ) and Idiomarina zobellii sp. nov. (type strain is KMM 231').
\end{abstract}

Keywords: deep-sea bacteria, new genus, new species, Idiomarina abyssalis, Idiomarina zobellii

\section{INTRODUCTION}

Marine bacteria belonging to Alteromonas, Pseudoalteromonas, Marinomonas, Halomonas and Oceanospirillum have been characterized as aerobic, Gramnegative, heterotrophic, mainly rod-shaped organisms

†Present address: Korean Collection for Type Cultures, Korea Research Institute of Bioscience and Biotechnology, PO Box 115, Yusong, Taejon 305600 , Republic of Korea.

The GenBank accession numbers for the $16 \mathrm{~S}$ rDNA sequences of Idiomarina abyssalis KMM $227^{\top}$ and Idiomarina zobellii $\mathrm{KMM} 231^{\top}$ are AF052740 and AF052741, respectively. isolated from seawater, algae and marine invertebrates (Baumann \& Baumann, 1981; Baumann et al., 1984; Gauthier \& Breittmayer, 1992; Gauthier et al., 1995; Dobson \& Franzmann, 1996). Identification of these oxidative marine bacteria at the species level remains difficult and time consuming, although members of the five genera cited above have phenotypic and chemotaxonomic features that differentiate them at the genus level. Representatives of these microorganisms are interesting in terms of their metabolic characteristics, psychrophilic nature, halotolerance and ubiquitous distribution in the marine environment. 


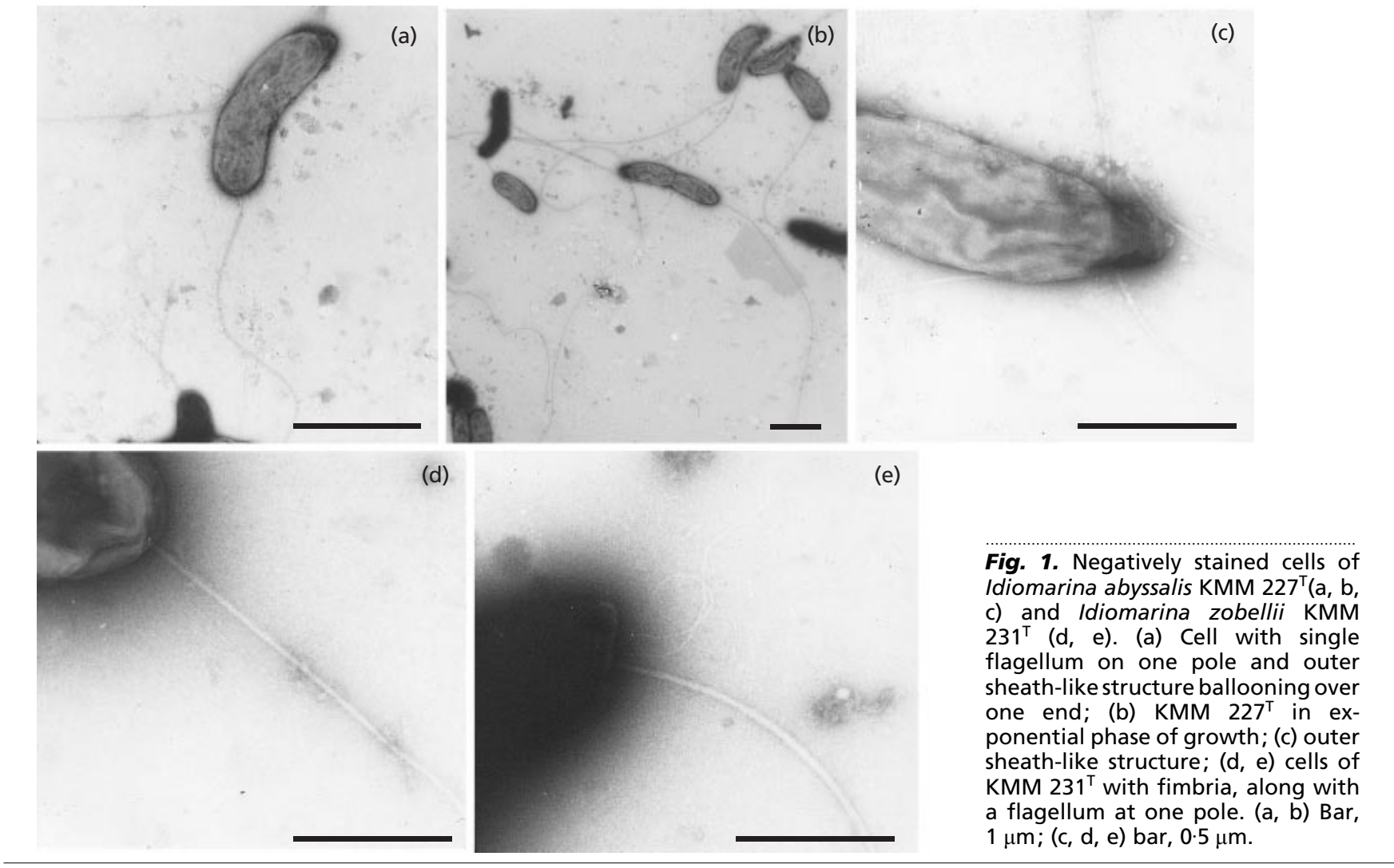

The presence of as yet undescribed novel bacterial taxa in a variety of extreme marine environments is indicative of the fact that they represent a resource of microbial diversity (Deming et al., 1988; Gauthier et al., 1992; Irgens et al., 1996; Bowman et al., 1997a, b; Bozal et al., 1997; Ràguénes et al., 1997). Characterization of two deep-sea isolates is reported here and, based on the polyphasic evidence obtained, it is proposed that they be classified as Idiomarina abyssalis sp. nov. and Idiomarina zobellii sp. nov., in a new genus, Idiomarina gen. nov.

\section{METHODS}

Sampling and isolation. Water samples were collected from a depth of $4000-5000 \mathrm{~m}$ (salinity, $34 \%$; temperature, $2{ }^{\circ} \mathrm{C}$ ) in the north-western area of the Pacific Ocean (latitude $8^{\circ} 20 \mathrm{~N}$, longitude $\left.133^{\circ} 0 \mathrm{~W}\right)$ during July, 1985. The deep water samples were collected using a standard hydrological plastic bathymeter. Isolation of the strains was achieved at atmospheric pressure by plating $0 \cdot 1 \mathrm{ml}$ seawater onto oligotrophic agar prepared with full-strength seawater, amended with $0.3 \%(\mathrm{w} / \mathrm{v})$ Bacto Peptone (Difco) and $1.5 \%(\mathrm{w} / \mathrm{v})$ Bacto Agar (Difco). The strains were subsequently purified on medium $\mathrm{B}$, containing $0.2 \%$ (w/v) Bacto Peptone, $0.2 \%$ $(\mathrm{w} / \mathrm{v})$ casein hydrolysate (Merck), $0 \cdot 2 \%(\mathrm{w} / \mathrm{v})$ Bacto Yeast Extract (Difco), $0 \cdot 1 \%$ (w/v) glucose, $0.002 \% \quad(\mathrm{w} / \mathrm{v})$ $\mathrm{KH}_{2} \mathrm{PO}_{4}, 0.005 \%(\mathrm{w} / \mathrm{v}) \mathrm{MgSO}_{4}$ and $50 \%(\mathrm{v} / \mathrm{v})$ natural seawater, as described elsewhere (Ivanova et al., 1996). The strains were maintained on a semisolid B medium, under mineral oil, at $4{ }^{\circ} \mathrm{C}$ and at $-80^{\circ} \mathrm{C}$ in Marine Broth (Difco) supplemented with $30 \%$ (v/v) glycerol. Alteromonas macleodii ATCC $27126^{\mathrm{T}}$, Vibrio cholerae ATCC $14035^{\mathrm{T}}$, Aeromonas jandaei ATCC $49568^{\mathrm{T}}$, Marinomonas communis ATCC $27118^{\mathrm{T}}$, Pseudoalteromonas haloplanktis subsp. haloplanktis IAM $12915^{\mathrm{T}}$ and Escherichia coli ATCC 25922 were employed as reference strains.

Phenotypic characterization. Standard methods developed for characterization of Alteromonas-like species were performed, as described by Baumann et al. (1972), Baumann \& Baumann (1981), Smibert \& Krieg (1994), and Ivanova et al. (1996, 1998). The following physiological and biochemical properties were examined: oxidation/fermentation of glucose ; arginine dihydrolase; accumulation of poly- $\beta$-hydroxybutyrate; cell pigmentation; cell morphology; Gram staining; motility; sodium requirement; oxidase and catalase production; and the ability to hydrolyse gelatin, agar, DNA, starch, Tween-80 and chitin. Anaerobic growth was tested using the Oxoid Anaerobic system. The requirement for $\mathrm{Na}^{+}$ ions was studied on medium that contained (w/v): $0.25 \%$ yeast extract, $0.1 \%$ glucose, $0.02 \% \mathrm{~K}_{2} \mathrm{HPO}_{4}, 0.005 \%$ $\mathrm{MgSO}_{4} \cdot 7 \mathrm{H}_{2} \mathrm{O}(\mathrm{pH} 7 \cdot 8)$. Salt tolerance tests were performed on Trypticase Soy Agar (TSA; Difco) with $\mathrm{NaCl}$ concentrations of $0.6-20.0 \%(\mathrm{w} / \mathrm{v})$. The temperature range for growth was determined on TSA containing $3 \%(\mathrm{w} / \mathrm{v})$ $\mathrm{NaCl}$; plates were incubated for $10 \mathrm{~d}$ at $4,10,15,20,25,30$ and $37^{\circ} \mathrm{C}$. The $\mathrm{pH}$ range for growth was determined in Marine Broth with the $\mathrm{pH}$ values of separate batches of media adjusted to $4,4 \cdot 5,5,6,7,8,8 \cdot 5,9,9 \cdot 5$ and 10 . The $\mathrm{pH}$ was adjusted with $10 \mathrm{M} \mathrm{NaOH}$ or $\mathrm{HCl}$.

Electron micrographs of negatively stained cells, using $1.25 \%$ uranyl acetate, were obtained using a Zeiss EM 10 CA electron microscope $(80 \mathrm{kV})$.

Utilization of various organic substrates, including amino acids, at $0 \cdot 1 \%(\mathrm{w} / \mathrm{v})$ as sole carbon source was performed 
Table 1. Characteristics differentiating Idiomarina species from related genera

Data obtained from this and earlier studies (D’Aoust \& Kushner, 1972; Baumann at al., 1984; Krieg, 1984; Vreeland, 1984; Deming et al., 1988; Bertone et al., 1996; Bowman et al., 1998). +, Trait present; -, trait absent; v, varies between strains; ND, not determined. Strains or genera: 1, I. abyssalis KMM 227 $; 2$, I. zobellii KMM 231 ${ }^{\mathrm{T}}$; 3, Alteromonas; 4, Colwellia; 5, Halomonas; 6, Marinomonas; 7, Oceanospirillum; 8, Pseudoalteromonas.

\begin{tabular}{|c|c|c|c|c|c|c|c|c|}
\hline \multirow[t]{2}{*}{ Characteristic } & \multicolumn{8}{|c|}{ Strain/genus } \\
\hline & 1 & 2 & 3 & 4 & 5 & 6 & 7 & 8 \\
\hline Cell diameter $(\mu \mathrm{m})$ & $0 \cdot 7-0 \cdot 9$ & $0 \cdot 7-0 \cdot 9$ & $0 \cdot 7-1 \cdot 0$ & $0 \cdot 5-1 \cdot 0$ & $0 \cdot 6-1 \cdot 1$ & $0 \cdot 7-1 \cdot 5$ & $0 \cdot 3-1 \cdot 4$ & $0 \cdot 2-1 \cdot 5$ \\
\hline \multicolumn{9}{|l|}{ Flagella arrangement: } \\
\hline Polar & + & + & + & + & + & - & + & + \\
\hline Bipolar & - & - & - & - & - & + & + & - \\
\hline Lateral & - & - & - & - & + & - & - & + \\
\hline Organelles & - & Fimbria & - & - & Filaments & - & - & - \\
\hline Metabolism & Aerobic & Aerobic & Aerobic & $\begin{array}{c}\text { Facultative } \\
\text { anaerobic }\end{array}$ & Aerobic & Aerobic & Aerobic & Aerobic \\
\hline \multicolumn{9}{|l|}{ Growth occurs: } \\
\hline in $\mathrm{NaCl}(\%)$ & $0 \cdot 6-15$ & $1-10$ & $1-6$ & $>2 \cdot 5$ & $0-20$ & $1-6$ & $0 \cdot 5-10$ & $1-9$ \\
\hline at $4{ }^{\circ} \mathrm{C}$ & + & + & - & + & $\mathrm{V}$ & - & - & $\mathrm{v}$ \\
\hline \multicolumn{9}{|l|}{ Presence of: } \\
\hline Poly- $\beta$-hydroxybutyrate & - & - & - & ND & + & - & + & - \\
\hline Gelatinase, lipase & + & + & + & + & - & - & - & + \\
\hline Chitinase & - & + & $\mathrm{V}$ & + & - & - & - & $\mathrm{V}$ \\
\hline Acid produced from sugars & - & - & + & + & + & + & - & + \\
\hline \multicolumn{9}{|l|}{ Utilization of: } \\
\hline D-Glucose & - & - & + & + & + & + & - & + \\
\hline D-Fructose & - & - & + & ND & + & + & - & $\mathrm{V}$ \\
\hline Mannitol & - & - & $\mathrm{V}$ & ND & + & + & - & $\mathrm{V}$ \\
\hline Sucrose & - & - & + & ND & + & - & - & $\mathrm{V}$ \\
\hline Maltose & - & - & + & + & + & $\mathrm{v}$ & - & $\mathrm{V}$ \\
\hline Lactose & - & - & + & ND & + & - & - & - \\
\hline Major fatty acid type & Iso-branched & Iso-branched & Straight & Straight & Straight & ND & Straight & Straight \\
\hline DNA $\mathrm{G}+\mathrm{C}$ content $(\mathrm{mol} \%)$ & 50 & 48 & $44-47$ & $40-46$ & $52-68$ & $45-50$ & $42-51$ & $37-50$ \\
\hline
\end{tabular}

using BM broth medium (Baumann et al., 1972). The bacterial cultures were incubated on a rotary shaker at 160 r.p.m. for $72 \mathrm{~h}$ at $26-28^{\circ} \mathrm{C}$. The ability to oxidize organic substrates was investigated using BIOLOG-GN plates. Strains were grown on marine agar plates at $28^{\circ} \mathrm{C}$ for $24 \mathrm{~h}$ and the cell density was adjusted to $\mathrm{OD}_{590}$ of $0 \cdot 3 \pm 0.05$ in $0.4 \mathrm{M} \mathrm{NaCl}$ solution. Three microplates were inoculated with 1501 cell suspension per well for each strain and incubated at $28^{\circ} \mathrm{C}$. The results were read visually, as recommended by Rüger \& Krambeck (1994), after incubation for 1, 2, 3 and $5 \mathrm{~d}$.

Susceptibility to antibiotics was tested by the conventional diffusion plate technique using solid B medium and disks were impregnated with the following antibiotics: kanamycin $(10 \mu \mathrm{g})$; ampicillin $(10 \mu \mathrm{g})$; benzylpenicillin $(10 \mu \mathrm{g})$; streptomycin $(10 \mu \mathrm{g})$; erythromycin $(15 \mu \mathrm{g})$; gentamicin $(10 \mu \mathrm{g})$; oxacillin $(20 \mu \mathrm{g})$; lincomycin $(15 \mu \mathrm{g})$; carbenicillin $(25 \mu \mathrm{g})$; vancomycin $(30 \mu \mathrm{g})$; tetracycline $(30 \mu \mathrm{g})$; oleandomycin $(15 \mu \mathrm{g})$; and $\mathrm{O} / 129(150 \mu \mathrm{g})$.

Cellular fatty acid analysis. Cellular fatty acid methyl esters were prepared and analysed using gas-liquid chromatography, according to Svetashev et al. (1995).

Determination of DNA base composition. DNA was prepared according to Marmur (1961) and DNA G + C content was determined using the thermal denaturation method (Marmur \& Doty, 1962).

DNA-DNA hybridization. Levels of genomic relatedness were determined by performing DNA-DNA dot blot hybridizations. Duplicate aliquots containing 100 and $200 \mathrm{ng}$ genomic DNA from Alteromonas macleodii, $V$. cholerae, Aeromonas jandaei, $M$. communis, P. haloplanktis subsp. haloplanktis and E. coli were denatured by boiling for $10 \mathrm{~min}$ in $6 \times \mathrm{SSC}(1 \times \mathrm{SSC}$ is $0.15 \mathrm{M} \mathrm{NaCl}$ plus $0.015 \mathrm{M}$ sodium citrate) and transferred onto Nylon membranes (Magnagraph) using a dot blot apparatus (BioRad). Prehybridization was carried out at $60^{\circ} \mathrm{C}$ for $30 \mathrm{~min}$ in hybridization buffer containing $5 \times \mathrm{SSC}$ and formamide $(35 \%, v / v)$. The same hybridization buffer was used for the prehybridization step as for the hybridization. Probe DNA of strain KMM $227^{\mathrm{T}}$ was prepared by boiling and labelling DNA, using DIG High Prime DNA labelling Kit II (Boehringer Mannheim). The resultant labelled DNA was added $\left(10 \mathrm{ng} \mathrm{ml}^{-1}\right)$ to the prehybridized membranes in hybridization buffer and the preparation was incubated at $65^{\circ} \mathrm{C}$ for $16 \mathrm{~h}$. The membranes were then washed twice in $2 \times \mathrm{SSC}$ and $0 \cdot 1 \% \mathrm{SDS}$ at room temperature followed by two washes in $0 \cdot 1 \times \mathrm{SSC}$ and $0 \cdot 1 \% \mathrm{SDS}$ at $65^{\circ} \mathrm{C}$ in a water bath with shaking. The degree of probe DNA binding was determined by means of chemoluminescence, using a DIG 
detection kit (Boehringer Mannheim) and X-ray film (Kodak). The chemoluminescent intensity of each blot was quantified using a densitometer (Molecular Dynamics). The signal produced by self-hybridization of the probe with homologous target DNA was taken as $100 \%$ and the percentage homology values were calculated for the duplicated dots.

16S rDNA analysis. PCR, cloning and sequencing of $16 \mathrm{~S}$ rDNA were carried out, using the Taq DyeDeoxy Terminator Cycle Sequencing kit (Applied Biosystems) and an Applied Biosystems 373A DNA sequencer, as described previously by Chun \& Goodfellow (1995). The resultant $16 \mathrm{~S}$ rDNA sequence was aligned manually against sequences obtained from the GenBank database. Phylogenetic trees were inferred using the Fitch \& Margoliash (1967), neighbour-joining (Saitou \& Nei, 1987) and maximumparsimony (Fitch, 1972) methods. Evolutionary distance matrices were generated according to Jukes \& Cantor (1969). The PHYLIP package (Felsenstein, 1993) was used for all analyses. The resultant tree topologies were evaluated in bootstrap analyses (Felsenstein, 1985) of the neighbourjoining method based on 1000 resamplings.

\section{RESULTS}

\section{Phenotypic characteristics of deep-sea isolates}

The isolates KMM $227^{\mathrm{T}}$ and KMM $231^{\mathrm{T}}$ were Gramnegative, strictly aerobic (able to grow by only oxidation in Leifson oxidation/fermentation medium), oxidase- and catalase-positive, non-pigmented, rodshaped bacteria, $0 \cdot 7-0.9 \mu \mathrm{m}$ in diameter and $1 \cdot 0$ $1.8 \mu \mathrm{m}$ long, with a single polar flagellum (Fig. 1a-d). Colonies were uniformly round, $2-3 \mathrm{~mm}$ in diameter, opaque, light yellowish after incubation for $48 \mathrm{~h}$ on marine agar. Strain KMM $227^{\mathrm{T}}$ had a single flagellum at one pole (Fig. 1a, b), whereas strain KMM $231^{\mathrm{T}}$ had scarcely visible long fimbria originating at one pole (Fig. 1c), along with a flagellum (Fig. 1d, e). Endospores were not observed for either strains. Poly- $\beta$ hydroxybutyrates were not found as an intracellular reserve product and the arginine dihydrolase system was not detected. Anaerobic growth was not observed. Neither strain required the addition of amino acids or vitamins for growth.

Both isolates required the addition of $1-10 \% \mathrm{NaCl}$ or seawater for growth. However, strain KMM $227^{\mathrm{T}}$ was able to grow at $\mathrm{NaCl}$ concentrations up to $15 \%(\mathrm{w} / \mathrm{v})$. The temperature range for growth was $4-30{ }^{\circ} \mathrm{C}$, with optimum growth at $20-22^{\circ} \mathrm{C}$. No growth was detected at $40^{\circ} \mathrm{C}$. The $\mathrm{pH}$ range of growth was $5 \cdot 5-9 \cdot 5$, with optimum growth at $\mathrm{pH} 7 \cdot 5-8 \cdot 0$. Agar and starch were not hydrolysed and only strain KMM $231^{\mathrm{T}}$ produced chitinase. Both strains produced gelatinase, lipase and DNase. Both strains showed a similar pattern of carbohydrate utilization as sole source of carbon and energy (Table 1). A limited number of carbon substrates were oxidized by the two isolates, as shown by BIOLOG test results. Utilization of selected compounds was found to differentiate the strains. The following were utilized by strain KMM $227^{\mathrm{T}}$ : $\alpha$-cyclodextrin, dextrin; glycogen; methylpyruvate; monomethylpyruvate; acetic, $\alpha$-ketobutyric, valeric,
Table 2. Cellular fatty acid composition ( $\%$ ) of Idiomarina strains used in this study

The number of carbon atoms and double bonds are indicated. The following fatty acids were present at less than $1 \%: 11: 0 ; 12: 0 ; 13: 0$; iso-14:0;14:1(n-7); 14:1(n-5); anteiso- $15: 0$; anteiso- $15: 1 ; 15: 1(\mathrm{n}-6)$; anteiso-16:0; $16: 1(\mathrm{n}-$ 9); anteiso-17:0; 17:0.

\begin{tabular}{|lcc|}
\hline Fatty acid & $\begin{array}{c}\text { Idiomarina } \\
\text { abyssalis } \\
\text { KMM 227 }\end{array}$ & $\begin{array}{c}\text { Idiomarina } \\
\text { zobellii } \\
\text { KMM 231 }^{\mathbf{T}}\end{array}$ \\
\hline iso-13:0 & $1 \cdot 0$ & $1 \cdot 1$ \\
iso-15:0 & $33 \cdot 7$ & $40 \cdot 6$ \\
iso-15:1 & $2 \cdot 3$ & $1 \cdot 6$ \\
$15: 1(\mathrm{n}-8)$ & $1 \cdot 3$ & $1 \cdot 1$ \\
$16: 0$ & $6 \cdot 3$ & $4 \cdot 6$ \\
$16: 1(\mathrm{n}-7)$ & $7 \cdot 0$ & $8 \cdot 3$ \\
iso-17:0 & $11 \cdot 9$ & $12 \cdot 5$ \\
$17: 1(\mathrm{n}-8)$ & $0 \cdot 8$ & $1 \cdot 1$ \\
$17: 1(\mathrm{n}-6)$ & $1 \cdot 5$ & $3 \cdot 4$ \\
$18: 0$ & $1 \cdot 8$ & $0 \cdot 8$ \\
$18: 1(\mathrm{n}-9)$ & $1 \cdot 4$ & $0 \cdot 9$ \\
$18: 1(\mathrm{n}-7)$ & $6 \cdot 7$ & $5 \cdot 9$ \\
Others & $0 \cdot 9$ & $0 \cdot 9$ \\
\hline
\end{tabular}

propionic and succinic acids; L-alanine; L-alanylglycine; glycyl-L-glutamic acid; L-proline, glycerol; and glucose 6-phosphate. However, the following were utilized by strain KMM $231^{\mathrm{T}}$ : monomethylsuccinate; $\alpha$-ketobutyric, valeric and succinic acids; alaninamide; L-alanine; L-alanylglycine; glycyl-L-glutamic acid; and L-ornithine.

The strains were resistant to kanamycin, ampicillin, benzylpenicillin, oleandomycin, lincomycin, tetracycline, oxacillin, vancomycin and $\mathrm{O} / 129$. Both strains were susceptible to erythromycin. In addition, strain KMM $227^{\mathrm{T}}$ was susceptible to streptomycin and gentamicin.

\section{Fatty acid composition}

Twenty-nine fatty acids, containing 11-18 carbon atoms, were detected (Table 2). The predominant fatty acids were odd-numbered and iso-branched (ca. $70 \%$ ). Saturated and monounsaturated fatty acids, namely $16: 0,16: 1(n-7), 18: 0$ and $18: 1(n-7)$, were found in minor quantities. Cyclopropane fatty acid was absent.

\section{DNA base composition}

DNA G + C compositions for strains KMM $227^{\mathrm{T}}$ and $231^{\mathrm{T}}$ were 50 and $48 \mathrm{~mol} \%$, respectively.

\section{Genotypic characterization}

The 16S rDNA sequences determined for the two isolates (1465 and $1464 \mathrm{nt}$ for strains KMM $227^{\mathrm{T}}$ and KMM $231^{\mathrm{T}}$, respectively) were useful in phylogenetic 


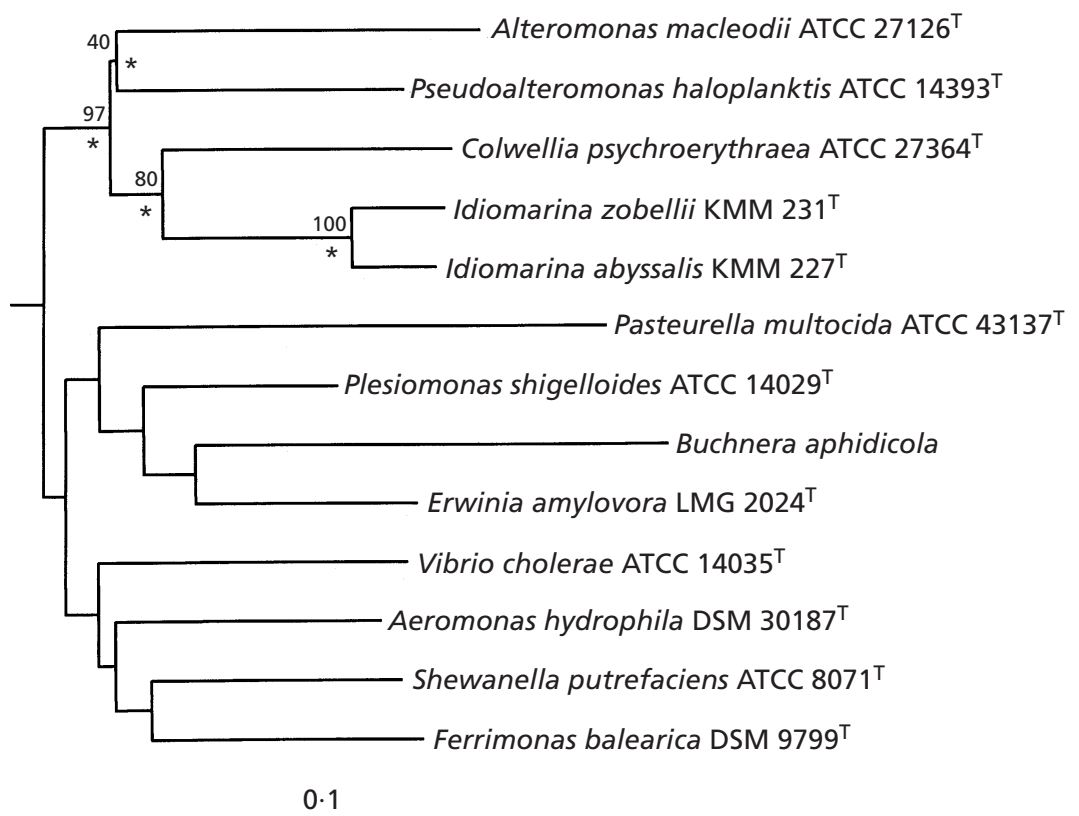

Fig. 2. Phylogenetic position of isolates KMM $227^{\top}$ and $\mathrm{KMM} 231^{\top}$ within the clade containing $\gamma$-Proteobacteria. The tree was constructed using neighbour-joining analysis based on 1387 unambiguously aligned 16S rRNA positions. The root was determined using an outgroup, Burkholderia cepacia (M22518). The numbers at the nodes are the levels of bootstrap support based on neighbour-joining analyses of 1000 resampled data sets, and asterisks indicate that the corresponding nodes (groupings) are also recovered in Fitch-Margoliash and maximum-parsimony trees. Scale bar, 0.1 nucleotide substitution per position. The accession numbers of the strains used are: X82145 (Alteromonas macleodii); X67024 (Pseudoalteromonas haloplanktis); AF001375 (Colwellia psychroerythraea); M35018 (Pasteurella multocida); X60418 (Plesiomonas shigelloides); L18927 (Buchnera aphidicola); Z96088 (Erwinia amylovora); Z21856 (Vibrio cholerae); X82133 (Shewanella putrefaciens); X87271 (Aeromonas hydrophila); and X93021 (Ferrimonas balearica).

analyses employing three different tree-making algorithms. The results clearly indicated that the two isolates were members of the $\gamma$-Proteobacteria and more closely related to each other than to any other bacteria whose sequences are available (nucleotide sequence similarity of $96.9 \%, 45$ differences out of 1462 positions). The next closest phylogenetic neighbour was Colwellia psychroerythraea $(90.5 \%$ and $90 \cdot 1 \%$ sequence similarity, for strains $\mathrm{KMM} 227^{\mathrm{T}}$ and KMM $231^{\mathrm{T}}$, respectively). This relationship was also evident in the phylogenetic tree, whereby the two strains formed a stable monophyletic clade, with a $100 \%$ bootstrap value (Fig. 2). Our isolates, together with Colwellia, Alteromonas and Pseudoalteromonas, were recovered in a suprageneric monophyletic clade recognized by all of the tree-making methods employed in this study and supported by high bootstrap values $(95 \%)$. The affiliation of our isolates and Colwellia psychroerythraea, supported by a relatively low bootstrap value of $78 \%$, was not observed in the maximum-parsimony tree.

When strain KMM $227^{\mathrm{T}}$ was used as a probe, DNA binding between the two isolates was $27 \%$. DNA relatedness values of strain KMM $227^{\mathrm{T}}$ and representatives of $\gamma$-Proteobacteria were 3-7\% (7\% with Alteromonas macleodii, $7 \%$ with $V$. cholerae, 3\% with Aeromonas jandaei, $7 \%$ with $M$. communis, $6 \%$ with P. haloplanktis subsp. haloplanktis and $3 \%$ with E. coli).

\section{DISCUSSION}

Two strains of heterotrophic marine bacteria were isolated from seawater samples collected at a depth of 4000-5000 m. The organisms were strictly aerobic, negative in the oxidation/fermentation test, non- pigmented, motile, oxidase- and catalase-positive, Gram-negative rods, with a DNA G $+\mathrm{C}$ content of 48-50 mol \%. Taxonomic characteristics of the strains were typical of the genera Alteromonas, Pseudoalteromonas and Marinomonas. However, representatives of the genera Alteromonas and Pseudoalteromonas differed from these isolates, notably in that they possessed a lower $\mathrm{G}+\mathrm{C}$ ratio, were rich in saturated and monounsaturated fatty acids in whole cell lysates, and were able to utilize an array of carbohydrates (Gauthier \& Breittmayer, 1992; Bertone et al., 1996). Similarly, members of the genus Marinomonas differed from our isolates in bipolar flagella arrangement and biochemical profile (Table 1). Halomonas spp., another oxidase-positive group of marine bacteria, resembled the isolates of this study in terms of salinity requirement but differed in fatty acid profile and peritrichous flagella and Halomonas spp. had significantly higher $\mathrm{G}+\mathrm{C}$ DNA content (ca. $63 \mathrm{~mol} \%$ ). Oceanospirillum species are distinct in cell morphology and phenotypic traits. It is, therefore, concluded that the deep-sea isolates can be separated from other described marine bacterial species by using a combination of phenotypic characters. Several phenotypic properties, including results of the BIOLOG tests, can be used to separate the two isolates (Table 1).

The microbial populations of the abyssal depths of the ocean can be both psychrophilic and barophilic. It is of particular interest that the isolates of this study revealed a wide range of physiological properties, growth on oligotrophic medium and within a broad range of temperatures, $\mathrm{pH}$ values and $\mathrm{NaCl}$ concentrations. In contrast to other Alteromonas-like bacteria, the deep-sea isolates exhibited a limited ability to utilize carbohydrates as sole source of carbon and 
energy (Table 1). Phylogenetic studies based on $16 \mathrm{~S}$ rDNA sequence analysis confirmed the hypothesis that the deep-sea bacteria represented a distinct line within the heterotrophic oxidative bacteria of the $\gamma$ Proteobacteria. It is evident from the phylogenetic tree and $16 \mathrm{~S}$ rDNA sequence similarity to other species ( $90 \%$ or less) that the lineage represented by the isolates of this study has some relationship with other genera, e.g. Alteromonas, Colwellia and Pseudoalteromonas. On the basis of $16 \mathrm{~S}$ rDNA sequence similarity $(96.9 \%)$ and DNA relatedness $(27 \%)$, it is also clear that these bacterial species do not belong to previously described genomic species (Wayne et al., 1987). It is, therefore, proposed that strains $\mathrm{KMM} 227^{\mathrm{T}}$ and KMM $231^{\mathrm{T}}$ be classified in a new genus Idiomarina gen. nov., as Idiomarina abyssalis sp. nov. and Idiomarina zobellii sp. nov., respectively.

\section{Description of Idiomarina gen. nov.}

Idiomarina [I.di.o.ma.ri'na. Gr. adj. idios original, true; L. fem. adj. marina of the sea, marine; M.L. fem. $\mathrm{n}$. Idiomarina pertaining to the peculiar, true marine nature of micro-organisms from the ocean (seawater)].

Gram-negative, strictly aerobic, chemo-organotrophic, oxidase-positive, asporogenous, motile, with single polar flagellum, rod-shaped cells occurring single, sometimes in pairs, about $0.7-0.9 \mu \mathrm{m}$ in diameter. Does not accumulate poly- $\beta$-hydroxybutyrate as an intracellular reserve product and does not have an arginine dihydrolase system. Organic growth factors not required, but sodium ions or seawater are required for growth. Temperature of growth is $4-30{ }^{\circ} \mathrm{C}$, with optimum growth occurring at $20-22{ }^{\circ} \mathrm{C}$. No growth detected at $40{ }^{\circ} \mathrm{C}$. The $\mathrm{pH}$ range for growth is $5 \cdot 5-9 \cdot 5$, with optimum growth occurring at $\mathrm{pH} 7 \cdot 5-8 \cdot 0$. Growth factors are not required. Gelatinase, lipase and DNase present but agar and starch not hydrolysed. Utilizes D-arginine and L-tyrosine as a sole source of carbon but not D-arabinose, D-rhamnose, D-mannose, sucrose, maltose, lactose, melibiose, glycerol, mannitol, L-lysine or L-phenylalanine. The following were utilized: $\alpha$-ketobutyric and $\alpha$-ketovaleric acids; alaninamide; L-alanine; and L-alanyl-glycine. D-Arabinose, D-rhamnose, Dmannose, sucrose, maltose, lactose, melibiose, glycerol, mannitol, L-lysine and L-phenylalanine were not utilized, according to BIOLOG tests. Susceptible to erythromycin but resistant to kanamycin, ampicillin, benzylpenicillin, lincomycin, tetracycline, oxacillin, oleandomycin, vancomycin and $\mathrm{O} / 129$. The predominant cellular fatty acids are odd-numbered, iso-branched (about $70 \%$ ), followed by saturated and monounsaturated straight fatty acids. DNA $\mathrm{G}+\mathrm{C}$ content is $48 \cdot 0-50 \cdot 4 \mathrm{~mol} \%$, (determined by thermal denaturation). A member of a phylogenetically coherent group, including the genera Alteromonas, Colwellia and Pseudoalteromonas, in the $\gamma$-Proteobacteria. The genus contains two species, Idiomarina abyssalis and Idiomarina zobellii, with I. abyssalis as the type species. Isolated from the deep sea.

\section{Description of Idiomarina abyssalis sp. nov.}

Idiomarina abyssalis [a.bys.sal'is. L. fem./masc. adj. abyssalis deep-sea; M.L. fem. adj. abyssalis of abyssal depths of the ocean $(1000-6000 \mathrm{~m})$ from which the organism was isolated].

In addition to the description given above for the genus, this species grows on nutrient media with $0 \cdot 6-15 \cdot 0 \% \mathrm{NaCl}$. Capable of oxidizing $\alpha$-cyclodextrin, dextrin, glycogen, methylpyruvate, monomethylsuccinate, acetic acid, glycyl-L-glutamic acid, Lproline, glycerol and glucose 6-phosphate (BIOLOG test results). Proteinase present. Susceptible to streptomycin and gentamicin. DNA $\mathrm{G}+\mathrm{C}$ content of $50 \cdot 4 \mathrm{~mol} \%$. The type strain is KMM $227^{\mathrm{T}}$.

\section{Description of Idiomarina zobellii gen. nov., sp. nov.}

Idiomarina zobellii (zo.bell'i.i. M.L. fem. adj. zobellii of Zobell; named after C. E. Zobell, a pioneer marine microbiologist).

In addition to the description for the genus, the species forms fimbria and utilizes monomethylsuccinate, Lornithine and glycyl-L-glutamic acid (BIOLOG test results). Grows on nutrient media with $1-10 \% \mathrm{NaCl}$. Chitinase present. DNA G $+\mathrm{C}$ content of $48 \mathrm{~mol} \%$. The type strain is KMM $231^{\mathrm{T}}$.

\section{ACKNOWLEDGEMENTS}

This study was supported by a short-term UNESCO Fellowship, by funds from the Russian Fund for Basic Research 96-04-49058 and 99-04-4817, and by a grant from the State Committee for Science and Technologies of the Russian Federation 96-03-19/97-03-19. In addition, partial support was provided by grant no. 1R01AI39129 of the National Institutes of Health and by grant no. R824995-01 from the US Environmental Protection Agency.

\section{REFERENCES}

Baumann, P. \& Baumann, L. (1981). The marine Gram-negative eubacteria; genera Photobacterium, Beneckea, Alteromonas, Pseudomonas, and Alcaligenes. In The Prokaryotes. A Handbook on Habitats, Isolation, and Identification of Bacteria, pp. 1302-1330. Edited by M. P. Starr, H. Stolp, H. G. Trüper, A. Balows \& H. G. Schlegel. Berlin: Springer.

Baumann, L., Baumann, P., Mandel, M. \& Allen, R. D. (1972). Taxonomy of aerobic marine eubacteria. $J$ Bacteriol 110, 402-429.

Baumann, P., Gauthier, M. J. \& Baumann, L. (1984). Genus Alteromonas. Baumann, Baumann, Mandel and Allen 1972. In Bergey's Manual of Systematic Bacteriology, pp. 243-354. Edited by N. R. Krieg \& J. G. Holt. Baltimore: Williams \& Wilkins

Bertone, S., Glacomini, M., Ruggiero, C., Piccarolo, C. \& Calegari, L. (1996). Automated systems for identification of heterotrophic marine bacteria on the basis of their fatty acid composition. Appl Environ Microbiol 62, 2122-2132.

Bowman, J. P., McCammon, S. A., Brown, J., Nichols, P. D. \& McMeekin, T. A. (1997a). Psychroserpens burtonensis gen. nov., sp. nov. and Gelidibacter algens gen. nov., sp. nov.: psychro- 
philic bacteria from Antarctic lacustrine and sea ice habitats. Int J Syst Bacteriol 47, 670-677.

Bowman, J. P., McCammon, S. A., Brown, M. V., Nichols, P. D. \& McMeekin, T. A. (1997b). Diversity and association of psychrophilic bacteria in Antarctic sea ice. Appl Environ Microbiol 63, 3068-3078.

Bowman, J. P., Gosink, J. J., McCammon, S. A., Lewis, T. E., Nichols, D. S., Nichols, P. D., Skerratt, J. H., Staley, J. T. \& McMeekin, T. A. (1998). Colwellia demingiae sp. nov., Colwellia hornerae sp. nov., Colwellia rossensis sp. nov., and Colwellia psychrotropica sp. nov.: a psychrophilic Antarctic species with

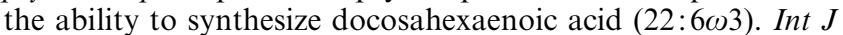
Syst Bacteriol 48, 1171-1180.

Bozal, N., Tudela, E., Rossello-Mora, R., Lalucat, J. \& Guinea, J. (1997). Pseudoalteromonas antarctica sp. nov., isolated from an Antarctic coastal environment. Int J Syst Bacteriol 47, 345-351.

Chun, J. \& Goodfellow, M. (1995). A phylogenetic analysis of the genus Nocardia with 16S rRNA gene sequences. Int $J$ Syst Bacteriol 45, 240-245.

D'Aoust, J. Y. \& Kushner, D. J. (1972). Vibrio psychroerythrus sp. n.: classification of the psychrophilic marine bacterium, NRC 1004. J Bacteriol 111, 340-342.

Deming, J. W., Somers, L. K., Straube, W. L., Swartz, D. G. \& MacDonnel, M. T. (1988). Isolation of an obligatory barophilic bacterium and description of a new genus, Colwellia gen. nov. Syst Appl Microbiol 10, 152-160.

Dobson, S. J. \& Franzmann, P. D. (1996). Unification of the genera Deleya (Baumann et al. 1983), Halomonas (Vreeland et al. 1980), and Halovibrio (Fendrich 1988) and the species Paracoccus halodenitrificans (Robinson and Gibbons 1952) into a single genus Halomonas, and placement of the genus Zymobacter into a family Halomonadaceae. Int J Syst Bacteriol 46, 550-558.

Felsenstein, J. (1985). Confidence limits on phylogenies: an approach using the bootstrap. Evolution 39, 783-791.

Felsenstein, J. (1993). PHYLIP (Phylogenetic Inference Package) version 3.5c. Seattle: University of Washington.

Fitch, W. M. (1972). Toward defining the course of evolution: minimum change for a specific tree topology. Syst Zool 20 , 406-416.

Fitch, W. M. \& Margoliash, E. (1967). Construction of phylogenetic trees: a method based on mutation distances as estimated from cytochrome $c$ sequences is of general applicability. Science 155, 279-284.

Gauthier, M. J. \& Breittmayer, V. A. (1992). The genera Alteromonas and Marinomonas. In The Prokaryotes, pp. 3046-3070. Edited by A. Balows, H. G. Trüper, M. Dworkin, W. Harder \& K.-H. Schleifer. New York: Springer.

Gauthier, G., Gauthier, M., Christen, R., Fernandez, L., Acquaviva, M., Bonin, P. \& Bertrand, J.-C. (1992). Marinobacter hydrocarbonoclasticus gen. nov., sp. nov., a new, extremely halotolerant, hydrocarbon-degrading marine bacterium. Int $J$ Syst Bacteriol 42, 568-576.

Gauthier, G., Gauthier, M. \& Christen, R. (1995). Phylogenetic analysis of the genera Alteromonas, Shewanella, and Moritella using genes coding for small-subunit rRNA sequences and division of the genus Alteromonas into two genera, Alteromonas (emended) and Pseudoalteromonas gen. nov., and twelve new species combinations. Int J Syst Bacteriol 45, 755-761.

Irgens, R. L., Gosink, J. J. \& Staley, J. T. (1996). Polaromonas vacuolata gen. nov., sp. nov., a psychrophilic, marine, gas vacuolate bacterium from antarctica. Int J Syst Bacteriol 46, 822-826.

Ivanova, E. P., Kiprianova, E. A., Mikhailov, V. V., Levanova, F. G., Garagulya, A. G., Gorshkova, N. M., Yumoto, N. \& Yoshikawa, S. (1996). Characterization and identification of marine Alteromonas nigrifaciens strains and emendation of the description. Int J Syst Bacteriol 46, 223-228.

Ivanova, E. P., Kiprianova, E. A., Mikhailov, V. V. \& 8 other authors (1998). Phenotypic diversity of Pseudoalteromonas citrea from different marine habitats and emendation of the description. Int J Syst Bacteriol 48, 247-256.

Jukes, T. H. \& Cantor, C. R. (1969). Evolution of protein molecules. In Mammalian Protein Metabolism, pp. 21-132. Edited by H. N. Munro. New York: Academic Press.

Krieg, N. R. (1984). Genus Oceanospirillum Hylemon, Wells, Krieg and Jannasch 1973. In Bergey's Manual of Systematic Bacteriology, pp. 104-110. Edited by N. R. Krieg \& J. G. Holt. Baltimore: Williams \& Wilkins.

Marmur, J. (1961). A procedure for the isolation of deoxyribonucleic acid from microorganisms. J Mol Biol 3, 208-218.

Marmur, J. \& Doty, P. (1962). Determination of the base composition of deoxyribonucleic acid from its thermal denaturation temperature. $J$ Mol Biol 5, 109-118.

Ràguénes, G. H. C., Peres, A., Ruimy, R., Pignet, P., Christen, R., Loaec, M., Rougeaux, H., Barber, G. \& Guezennec, L. G. (1997). Alteromonas infernus sp. nov., a new polysaccharide-producing bacterium isolated from deep-sea hydrothermal vent. $J$ Appl Microbiol 82, 422-430.

Rüger, H.-J. \& Krambeck, H.-J. (1994). Evaluation of the BIOLOG substrate metabolism system for classification of marine bacteria. Syst Appl Microbiol 17, 281-288.

Saitou, N. \& Nei, M. (1987). The neighbor joining method: a new method for constructing phylogenetic trees. Mol Biol Evol 4, 406-425.

Smibert, R. M. \& Krieg, N. R. (1994). Phenotypic characterization. In Methods for General and Molecular Bacteriology, pp. 607-654. Washington, DC: American Society for Microbiology.

Svetashev, V. I., Vysotskii, M. V., Ivanova, E. P. \& Mikhailov, V. V. (1995). Cellular fatty acid of Alteromonas species. Syst Appl Microbiol 18, 37-43.

Vreeland, R. H. (1984). Genus Halomonas Vreeland, Litchfield, Martin and Elliot 1980. In Bergey's Manual of Systematic Bacteriology, pp. 340-343. Edited by N. R. Krieg \& J. G. Holt. Baltimore: Williams \& Wilkins.

Wayne, L. G., Brenner, D. J., Colwell, R. R. \& 9 other authors (1987). International Committee on Systematic Bacteriology. Report of the ad hoc committee on reconciliation of approaches to bacterial systematics. Int J Syst Bacteriol 37, 463-464. 